\title{
Processos sociais de vitimização prisional
}

\author{
Odilza Lines de Almeida e Eduardo Paes-Machado
}

Introdução

A pena traz em si uma consciente intenção de infligir dor que está presente no significado da palavra "penal” em várias línguas ocidentais (cf. Christie, 1988), incluindo a portuguesa. Daí que falar de vitimização no sistema prisional, que, a priori, cumpre plenamente esta finalidade, pode parecer um contrassenso. Não foi para isso mesmo que a pena foi criada, apesar dos argumentos civilizados de dissuasão e retribuição? Esta não esteve sempre associada a algum tipo de dor? (cf. Alvarez, 2008)

Além do leitmotiv vingativo da pena, outro aspecto que poderia caracterizar este aparente contrassenso é o fato de o prisioneiro não ser uma vítima ideal (cf. Christie, 1986), isto é, não ser aquela pessoa que, quando agredida, recebe a imediata atenção do público, pois não aparenta ser fraca ou mesmo "respeitável". Nessa linha, vítimas ideais necessitam de ofensores ideais: maus, fortes, estranhos à sociedade (cf. Idem, ibidem), e os prisioneiros estão encapsulados nesse rótulo. Vê-los como vítimas requer, em algumas situações, um esforço cognitivo que nem sempre o público está disposto pelos sentimentos vingativos subjacentes à punição. Ademais, a essencialização desses papéis de vítima e perpetrador -, pelo senso comum e pelo sistema de justiça criminal, impede que eles sejam vistos como o que realmente são: lugares sociais mutáveis e permutáveis. 
1. Para Sá (1996, p. 15), a vitimização é "um processo pelo qual alguém (que pode ser uma pessoa, grupo, um segmento da sociedade, país) torna-se ou é eleito a tornar-se um objeto da violência por parte de outrem (que também poderá ser uma pessoa, grupo etc.)". A vitimização também pode ser socioestrutural (delitos relacionados com ódio, situaçóes sociais específicas etc.), coletiva (contra um grupo ou população inteira) e institucional, que se refere à vitimização de uma instituiçăo ou por uma instituiçăo. Esta última interessa a este trabalho, posto que acontece, com muita frequência, em lugares como a prisão (cf. Colorado, 2006).
Assim, não é fortuito que, embora a vitimização prisional figure na maioria dos estudos (cf. Clemmer, 1940; Sykes, 1958; Sparks, Bottoms e Hay, 1996; Chubaty, 2001; Cooley, 1993; Viggiani, 2007; Edgar, O’Donnel e Martin, 2003; Byrne, Hummer e Taxman, 2007; Wolff, Shi e Bachman, 2008; Wolff e Shi, 2011; Ireland, 2000, 2002; Paixão, 1987; Ramalho, 2002; Coelho, 2005; Alvarez, 2008), a discussão sistemática sobre o tema seja recente. Entendida como qualquer incidente, provocado por conflitos endêmicos no cárcere, no qual uma pessoa é ameaçada, abusada e agredida (cf. Edgar, 2005), esta vitimização se diferencia da de outros grupos populacionais ${ }^{1}$ por três razões. Primeiramente, por sua aceitação, apesar das mudanças e variações internacionais e locais, por parte do público, das autoridades e dos próprios internos. Segundo, pela influência deletéria do confinamento e convívio compulsório de pessoas com trajetórias diversas em um ambiente regulado e de bens escassos (cf. Clemmer, 1940; Sykes, 1958; Edgar, O’Donnell e Martin, 2003). Terceiro, pela vulnerabilidade decorrente de atividades rotineiras altamente restritas, repetidas e partilhadas (cf. Chubaty, 2001).

A partir de uma perspectiva horizontal - indivíduos versus indivíduos - e limitada ao intramuros, Edgar, O’Donnell e Martin (2003) analisaram a violência prisional com base em seis dimensões conflituais: os interesses em jogo, a distância social entre os envolvidos (e a participação de terceiros interessados no episódio), os catalisadores (ou táticas) usados no conflito, a interpretação sobre os comportamentos dos adversários, os propósitos dados para o uso da força física e o contexto social em que são tomadas as decisões. Por sua vez, Byrne e Hummer (2007) apontaram uma correlação positiva entre densidade populacional e consequências adversas aos internos, incluindo níveis de violência, aumento da violência autoinfligida, percepção de agressão, consumo de drogas. Outras variáveis também estariam relacionadas com a violência prisional, como o perfil da população, as práticas gerenciais, a qualidade e a proporção staff-preso, o contexto situacional e a implementação de programas de tratamento.

Numa abordagem hierarquizante e relacional, Byrne, Hummer e Taxman (2007) consideram que o elevado nível de violência nas prisões norte-americanas espelha o da sociedade, devido à estreita relação entre as culturas interna e externa e à influência das quadrilhas de internos (prison gangs). $\mathrm{O}$ mesmo ponto é enfatizado por Stowell e Byrne (2007) quando afirmam que o comportamento dos prisioneiros é influenciado pelas normas vigentes nas instituiçôes correcionais e em seus respectivos grupos de origem. Ainda nessa linha, as experiências únicas do encarceramento podem exacerbar o potencial 
preexistente nos internos para a violência. Entretanto, de acordo com Hemmens e Marquart (1999), a percepção do nível de violência varia em função da idade e da carreira criminosa, bem como da aceitação da violência, já mencionada, que faz com que muitas ocorrências sejam vistas como inevitáveis ou não sejam declaradas pelos internos.

Neste trabalho, discutimos os padrões de vitimização de internos da maior unidade prisional da Bahia. Quais são estes padrões? Quais processos sociais e organizacionais (cf. Giddens, 2003; Walklate, 2003; Paes-Machado e Nascimento, 2011) os estruturam? Quais os fatores da vulnerabilidade dos presos? Dados os conflitos endêmicos e o caráter limitado das atividades rotineiras na prisão, argumentamos que, por um lado, tais padrões são influenciados pela violência da instituição, dos arranjos da cadeia (jail arrangements) e, principalmente, das quadrilhas de internos; por outro, a disponibilidade de capitais econômico, social e cultural (cf. Bourdieu, 1989) afeta os níveis de vulnerabilidade dos presos. Além das seçôes introdutória, metodológica e histórica, este artigo tem mais duas outras: uma sobre a vitimização institucional, interpessoal e grupal e outra acerca dos fatores de vulnerabilidade, seguidas pela conclusão.

\section{Trabalho de campo}

A pesquisa foi desenvolvida entre 2007 e 2010, em uma instituição penal do estado da Bahia, mediante a inserção de um dos pesquisadores no corpo funcional da mesma (cf. Almeida, 2011). Desde o primeiro dia, utilizou-se o diário de campo para registro de impressóes e informaçôes. A coleta de dados dividiu-se em três etapas. De início, foi feito o reconhecimento do espaço, da estrutura de funcionamento e dos atores da unidade. Em seguida, passou-se para uma fase ativa de busca de informaçóes, com entrevistas mais estruturadas com internos e funcionários, no intuito de conhecer a organização e identificar participantes. Terceiro, os contatos foram focalizados nos internos que sofreram ou infligiram agressões. Permeando essas etapas, a observação do ambiente prisional, com a ajuda de pessoas-chave, foi fundamental para a compreensão do conjunto e a identificação dos passos a serem seguidos. Outro recurso foi o acesso aos documentos acerca dos funcionários e das sindicâncias envolvendo faltas disciplinares.

O grupo de participantes foi composto de forma aleatória por aqueles que transitaram pelo setor de saúde da penitenciária - por razões médicas ou psicológicas - e, por conveniência, quando sabido que pertenciam ao 
grupo-alvo, e ainda por internos identificados por meio de entrevistas exploratórias, por agentes penitenciários e pelos registros dos livros de ocorrência e sindicância. A quantidade de participantes foi definida pelo critério de saturação. Além de presidiários, foram selecionados agentes penitenciários, técnicos, diretores, ex-diretores. De uma população aproximada de 1350 internos, fizemos um screening survey com 591 deles para identificação de possíveis participantes, sendo 531 custodiados no regime fechado e sessenta, no semiaberto. Deste total, 107 foram entrevistados em profundidade. Os encontros duraram, em média, quarenta minutos, mas houve situaçôes de múltiplos encontros com cerca de $40 \%$ deles. O perfil da amostra dos 591 internos participantes do screening survey confirma a seletividade sociorracial extrema do sistema prisional: $47 \%$ eram reincidentes, $51,8 \%$ deles tinham até 30 anos, quase $85 \%$ eram negros ou pardos, $53,6 \%$ cursaram até o primeiro ciclo do ensino fundamental e exerciam profissóes pouco especializadas, como ajudante (16\%), lavrador $(12,4 \%)$, pedreiro $(6,8 \%)$, pintor $(5,1 \%)$ e mecânico $(3,1 \%)$.

Vale observar que as agressões relatadas pelos internos não estão restritas à unidade prisional focalizada, mas incluem eventos ocorridos durante todo o tempo de custódia deles nas várias unidades do sistema prisional. Tal decisão deveu-se a que, por conta do trânsito dos presos entre essas unidades, uma grande parte da sua vitimização é processual. $\mathrm{O}$ mesmo artifício permitiu maior conhecimento desses incidentes, visto que os internos se sentiam mais à vontade para falar de situaçôes que, em princípio, foram vivenciadas nessas outras unidades ou até fora do sistema prisional, mas com repercussões maiores sobre este do que sobre a unidade em tela. Cabe ainda ressaltar que, devido ao grande número de entrevistados, adicionamos letras às suas idades para mostrar que não se trata da mesma pessoa.

\section{Panorama das prisões}

A história das prisões brasileiras é marcada pela discriminação, injustiça e violência. Os primeiros estabelecimentos do país foram instituídos para os escravos fujōes e os malfeitores das cidades e vilas coloniais. Nessa época, as cadeias eram espaços regulados pelo costume, que garantiam segurança às classes proprietárias e operavam via detenção daqueles que, já condenados, aguardavam a execução de suas sentenças (cf. Aguirre, 2009).

A Casa de Correição da Corte (Complexo Frei Caneca), no Rio de Janeiro, inaugurada em 1834, e seguida pela construção, em 1856, de uma 
Casa de Detenção anexa, foi a primeira instituição penal brasileira que incorporou características do modelo panóptico de Bentham (cf. Porto, 2007). Essa instituição estabelecia o regime de cela única e tinha como tecnologia punitiva a reabilitação do preso mediante o trabalho obrigatório diurno e isolamento noturno. Embora estas e outras casas de correição tenham sido concebidas como ilhas de excelência para romper com a situação até então existente, elas não alcançaram esse intento. Além de hospedar presos correcionais, não sentenciados, possuíam recintos especiais, o calabouço, destinado a abrigar escravos fugitivos ou depositá-los para que recebessem a pena de açoite. Na falta de espaço, muitos eram mandados para a ilha de Fernando de Noronha (cf. Carvalho Filho, 2002; Salla, 1999) ou, ainda, alistados à força no Exército, que se transformou, desse modo, em uma importante instituição penal no século XIX (cf. Aguirre, 2009).

No início da República, após a libertação de quase 1 milhão de escravos, o regime carcerário se expandiu para acomodar a crescente penalização de pequenos crimes antes tolerados, como jogo e vadiagem, resultando no crescimento da entrada de pessoas na Casa de Detenção do Rio de Janeiro e na ampliação do número de colônias penais (cf. Chazkel, 2009). Embora a República tenha criado um novo Código Penal, ela pouco alterou as condiçōes dos estabelecimentos penais existentes. $\mathrm{O}$ novo regime, entretanto, fundou instituiçôes exclusivas para crianças, jovens abandonados e infratores. A partir dos anos de 1930, as prisões passaram a abrigar, lado a lado com os presos comuns, muitos presos políticos que vivenciaram e registraram, no caso do famoso escritor Graciliano Ramos, as horríveis condiçôes carcerárias na época. Essa prática, que também foi adotada pelo regime ditatorial vigente entre 1964 e começo dos anos de 1980, acabou contribuindo, pelas trocas culturais entre presos políticos e comuns, para a profissionalização do crime e formação das primeiras quadrilhas prisionais no Rio de Janeiro.

$\mathrm{Na}$ atualidade, as prisões brasileiras caracterizam-se pela superpopulação, insalubridade, confinamento permanente, falta de investimentos governamentais e violência entre organizaçôes criminosas (cf. ONU, 2012). Aliados a isso, fatores como o aumento dramático da população carcerária, a mistura atabalhoada de condenados por diferentes tipos de delitos, a transferência de chefes do crime para cadeias de diferentes estados e o baixo investimento em inteligência possibilitaram a consolidação de quadrilhas ligadas ao comércio de drogas ilegais nas prisões do Rio de Janeiro e São Paulo e, posteriormente, da Bahia. De modo geral, tais grupos converteram a prisão, antes um inferno olvidado, em uma retaguarda estratégica, um balcão de negócios 
2. Dados do Ministério da Justiça, relativos a junho de 2010 , mostram que cerca de $11 \%$ dessas pessoas estão custodiadas em delegacias.

3. Dados do International Centre for Prison Studies, do King's College London, disponíveis em <http://www.prisonstudies. org/info/worldbrief/wpb_stats. php?area $=$ all \&category $=w b_{-}$ poptotal>, consultado em $27 / 6 / 2012$.

4. Em comparaçăo, Birkbeck (2010) indica que nos Estados Unidos a relação guarda/interno era em média 1:23 e, na Venezuela, 1:65.

5. As taxas que indicam que $20,6 \%$ da população foi vítima de, no mínimo, uma ameaçal agressão (cf. Borges, 2008, p. 88) são menores do que as encontradas neste estudo. Considerando que os participantes da pesquisa estavam no sistema prisional em média por 4 anos e 7 meses, utilizamos taxas de prevalência de vitimização da população em geral, nos últimos cinco anos, para fins de comparação meramente ilustrativa com os nossos achados, e não conclusiva, em virtude da metodologia que empregamos.

6. Na primeira tabela, a base de cálculo é o número total de eventos reportados e, na segunda, o número total de internos que reportaram terem sido vitimizados. Dessa forma, foram consideradas, no primeiro caso, as vitimizaçốes múltiplas e repetidas e, no segundo, apenas a vitimização múltipla. e uma central de comando do crime. Ademais, a governança das unidades prisionais passou a depender, em muitos casos, da cessão de poder estatal, também chamada de "negociação", para esses grupos.

O Brasil possui hoje mais de meio milhão de pessoas presas - a quarta população após Rússia, China e Estados Unidos - em instituições de diversos tipos e regimes. Isso significa uma taxa de 260 presos por $100 \mathrm{mil}$ habitantes $^{2}$, a qual situa o país no $49^{\circ}$ lugar do ranking mundial ${ }^{3}$. Quanto ao sistema penitenciário baiano, ele conta com 9455 pessoas custodiadas em 23 estabelecimentos penais (cf. Brasil, 2011). Essa população é predominantemente masculina - mais de $95 \%$ do total - e composta por pessoas que estão aguardando sentenças definitivas ou já foram condenadas a cumprir penas em unidades de regime fechado, aberto ou semiaberto. Somando 4412 pessoas custodiadas em carceragens policiais, a população totalizava, em 2011, 13867 encarcerados, o que representava uma taxa de 98,9 presos por 100 mil habitantes. No que se refere à penitenciária onde este estudo foi conduzido, ela é a maior instituição penal do estado, com quase 1350 presos sentenciados por homicídio (32,8\%), roubo e furto $(25,6 \%)$, tráfico de drogas (20,6\%), estupro (16,5\%) e outros delitos. Os sentenciados estão misturados, seguindo uma tecnologia gerencial rudimentar, em quatro pavilhões. Cada pavilhão possui um grupo de sete agentes penitenciários por plantão e cerca de 340 internos. Disso resulta uma razão diária de um agente para cada 49 presos por pavilhão, aí incluído o pessoal da escolta externa ${ }^{4}$, o que é uma medida da dificuldade de supervisão dos confinados e do elevado grau de autonomia destes e da sua organização informal.

Enfim, tanto no passado como no presente, o sistema prisional vem se caracterizando por ser o lugar dos "pobres, pretos e prostitutas", como dizem os brasileiros, e daqueles que, também de acordo com uma concepção moral disseminada, estão desprovidos de humanidade (cf. Misse, 2011).

\section{Índices de vitimização}

O índice de vitimização dos presos, durante todo o tempo de custódia e em várias unidades penais, é mais do que o dobro do da população em geral (20,6\%), segundo Borges (2008, p. 88) $)^{5}$ É assim que, dos 591 internos contatados pelo screening survey, mais da metade (54,3\%) afirmou ter sofrido algum tipo de agressão. Por sua vez, entre as 371 referências obtidas, foram identificados vários tipos e subtipos de vitimização (Tabelas 1 e 2$)^{6}$. 
Conquanto as agressões diretas entre os internos sejam mais do que o dobro da vitimização pelas instituições penais, existem variações importantes na sua distribuição entre os agentes. Enquanto os níveis das agressões físicas $(38,0 \%)$ e psicológicas $(22,1 \%)$ entre os presos superam os das instituições (10\% e 4,8\%), a participação destas últimas na vitimização material é quase duas vezes maior do que entre aqueles ${ }^{7}$. Tal proximidade entre os índices de vitimização física e material entre os internos aponta para uma das condições de maior vulnerabilidade, pois grande parte dos presos que declarou ter sofrido agressão física também experimentou perdas materiais. Digno de nota é o fato de que a vitimização pela instituição é constante, contínua, foi relatada em um bloco único e assim computada. Em contraste, a agressão física entre os pares foi reportada em episódios e contabilizada em número de vezes, apresentando, desse modo, maior prevalência (Tabela 1$)^{8}$.

\section{TABELA 1}

Vitimização direta por tipo e agente (\%)

\begin{tabular}{l|l|l|l}
\hline \multirow{2}{*}{ TIPO } & \multicolumn{2}{|c|}{ AGENTE VITIMIZADOR } & \multirow{2}{*}{ TOTAL } \\
\cline { 2 - 3 } & Instituição* & Outro prisioneiro & \\
\hline Física & 10,0 & 38,0 & 48,0 \\
Material & 15,9 & 9,2 & 25,1 \\
Psicológica & 4,8 & 22,1 & 26,9 \\
\hline TOTAL & 30,7 & 69,3 & 100,0 \\
\hline \hline
\end{tabular}

* Também denominada de organização formal do estabelecimento.

TABELA 2

Distribuição das ocorrências por tipo (\%)*

\begin{tabular}{l|l}
\hline \multicolumn{1}{c|}{ TIPO } & \multicolumn{1}{c}{ TOTAL (\%) } \\
\hline Direta Física & 37,3 \\
Material & 35,6 \\
Psicológica & 29,2 \\
Indireta & 4,7 \\
\hline \hline
\end{tabular}

* Há casos de mais de um relato por interno.

Em uma perspectiva comparativa, a taxa de 37,3\% de vitimização física é muito superior à das pesquisas de Edgar, O’Donnell e Martin (2003) e Wolff et al. (2007), assim como à de outro estudo com presos de Ohio, que encontrou a taxa de $10 \%$ de vitimização física e $48 \%$ de vitimização
7. Vale lembrar que consideramos apenas as vitimizações relatadas como tais pelos participantes. Logo, embora não possamos afirmar que a frequência encontrada retrate os números reais das ocorrências, podemos sustentar que estas estão mais presentes no cotidiano de cada um deles a ponto de serem citadas. É plausível também supor que os dados indicam uma estimativa mínima de vitimização se levarmos em conta que muitos dos internos não estão preparados para admitir que foram agredidos ou agrediram alguém.

8. Em contraste, Kimmet Edgar, Ian O'Donnell e Carol Martin (2003) encontraram dados inferiores entre adultos em prisões britânicas, envolvendo os diversos tipos de vitimização em tela no mês anterior à pesquisa. Tais índices são: agressão (19\%), ameaças de violência (26\%), roubo (4\%) e roubo em cela $(34 \%)$, abuso verbal $(26 \%)$ e exclusão (7\%) (Tabela 2). Por sua vez, o estudo de Wolff et al. (2007) com 7221 homens adultos presos mostrou que $25 \%$ deles foram agredidos pelos pares no período de encarceramento. 
9. As consequências da prisão podem ser necessárias, acessórias e abusivas. As necessárias estão relacionadas com a perda de liberdade e com tudo que advém disso: disrupção da família e dos laços sociais, um estado de existência compulsório e a necessidade de conformidade às regras. As acessórias são: dieta compulsória, meios de repouso desconfortáveis, exclusão da sociedade, associação forçada com companhias indesejadas, ausência dos meios de comunicaçăo com o mundo exterior, trabalho forçado ou ociosidade compulsória. As abusivas ou excesssivas seriam a tortura dissimulada, não consistente com a nossa civilização (cf. Bentham, s/d, apud Mouat, 1891). múltipla - por furto, roubo e agressão - nos últimos seis meses da pesquisa (cf. Wooldredge, 1998, apud Pérez et al., 2010). Esta última taxa de prevalência está mais próxima da do nosso estudo para a vitimização durante todo o período do encarceramento $(54,3 \%)$.

\section{Vitimização institucional}

Os danos provocados pela organização formal do estabelecimento ou pelo Estado (State harm) (cf. Ward, 2004) estão relacionados com as privações excessivas que, extrapolando o necessário ou legalmente estipulado, sobrepenalizam o indivíduo custodiado (cf. Bentham, s/d, apud Mouat, 1891) ${ }^{9}$. Tais danos são materiais, físicos e psicológicos (Tabela 1).

Uma grande parte dos danos materiais (15,9\%) também é física, a exemplo do não fornecimento de bens e serviços essenciais, como água potável, alimentação adequada, material de higiene e limpeza, colchões, assistência médica etc. As condições gerais de insalubridade e a falta de assistência favorecem a prevalência mais elevada de doenças infectocontagiosas nessas instituições do que entre a população em geral. Embora, em alguns casos, não se possa precisar se foram adquiridas dentro ou fora da instituição, as suas características facilitam o contágio e a aquisição de moléstias típicas de grupamentos e da falta de cuidados à saúde (cf. Nogueira e Abrahão, 2009; Martelli et al., 1990; Sánchez et al., 2007; Coelho et al., 2009).

As agressões físicas nas carceragens e outras unidades penais chegam a atingir $10 \%$. No caso das agressóes derivadas do uso da força policial - que acontecem em situações de crise, agressões e motins contra o staff, e revistas de celas de internos perigosos -, elas são acompanhadas pela destruição de pertences pessoais escassos, imantados de carga afetiva e simbólica.

A vitimização psicológica (4,8\%), por sua vez, reflete-se em sentimentos de humilhação, insegurança e vulnerabilidade. Vivendo nesse ambiente embrutecedor, os presos sentem-se desamparados e humilhados pela dependência de serviços precários e inoperantes, e por jogos de interesses e trocas em que eles são, muitas vezes, o lado mais fraco. Eles também se ressentem da exposição pública dos delitos por eles cometidos - como roubos a bancos, tráfico internacional de drogas, estupro etc. -, que agravam a situação de risco e deixam marcas indeléveis: "Quando cheguei na [ala de] observação o guarda falou pros outros 'esse aqui é estuprador'; e aí fiquei com medo. Não dormi de noite" (Interno, 28[b] anos). A negação de direitos fundamentais se expressa na exposição do corpo à violência por aqueles que deveriam 
cuidar dele, assim como na falta de iniciativas consistentes para prevenir e proteger os custodiados desta e de outras muitas agressóes. Todos esses fatores concorrem para a desconfiança no sistema penal e para a sensação de insegurança que acompanham o interno em sua trajetória carcerária.

\section{Organização informal da vitimização}

Ao lado da organização informal dos funcionários e do pessoal de segurança, a organização dos presos compreende os arranjos da cadeia, as quadrilhas criminosas e as redes sociais. Os arranjos da cadeia, formados em torno de veteranos sagazes e agressivos, envolvem práticas, valores e normas visando sobrevivência, manutenção de rotinas e exploração das oportunidades ilícitas oferecidas pelo cárcere. Apesar da sua notável criatividade, autonomia e persistência ao longo do tempo, tais arranjos ambivalentes - protetores e violentos - perderam parte do seu espaço para as quadrilhas dedicadas ao tráfico de drogas, roubos e extorsões, que se consolidaram nas prisões da Bahia a partir do final dos anos de 1990.

Efetivamente, as três principais quadrilhas (e suas dissidências) existentes constituem os principais centros de gravidade da cadeia. Além de dominarem aspectos vitais do estabelecimento - como espaço, segurança, trabalho, acesso preferencial e oportunidade de comercialização de bens e serviços permitidos e contrabandeados -, elas comandam e facilitam a solução de problemas da população carcerária (cf. Paixão, 1987). Ao mesmo tempo em que implantaram uma organização capilar, fundada em líderes de celas, galerias e pavilhões e na obediência a regras rígidas de convivência, elas se converteram em parceiras indispensáveis da governança prisional.

Dados os imperativos dos seus negócios criminosos, das relações concorrenciais mútuas e da visibilidade pública de suas operações, incluindo o aumento relativo da accountability do sistema prisional, cada quadrilha busca gerenciar as decisões relativas às agressões físicas, aos homicídios, às extorsões etc. Elas tanto concentram parte da violência difusa - instrumental e expressiva (cf. Chambliss, 1967; Cohn e Rotton, 2003) ${ }^{10}-$ dos arranjos de cadeia, como não hesitam em acionar a coerção nas suas relações com os internos e as quadrilhas rivais. Por conseguinte, essas quadrilhas têm poder para determinar as consequências dos conflitos (cf. Edgar, O’Donnell e Martin, 2003), assim como para redefini-los e gerar novos conflitos.

Quanto às redes sociais (cf. Hannerz, 1980) dos internos, integradas por comparsas (cf. Byrne, Hummer e Taxman, 2007), funcionários, familiares
10. Entendidas como polos extremos de um continuum, a violência instrumental está voltada para fins, enquanto a violência expressiva se refere às agressôes impulsivas ou afetivas (cf. Chambliss, 1967; Cohn e Rotton, 2003). 
11. A vitimização divide -se em: primária (relativa às consequências físicas, econômicas ou psicossociais de um delito), secundária (derivada das relaçōes da vítima com a justiça e suas redes sociais) e terciária (comportamento de vingança causado pela agressão sofrida) (cf. Colorado, 2006). A vitimização primária pode ser direta ou indireta. Enquanto a primeira refere-se a ser alvo de violência, a segunda remete ao testemunho ou informação sobre atos violentos contra pessoas próximas (cf. Cárdia, s/d). Ambas podem, ainda, ser múltiplas ou repetidas. A vitimização múltipla decorre da exposição a tipos distintos de violência, e a repetida, ao mesmo tipo de violência ou crime (cf. Hope, 2001). e outros, elas afetam e são afetadas pelos processos em tela. Embora só tenhamos abordado a prestação de apoio e a violência sofrida pelas redes familiares, não se pode perder de vista o papel das redes delituosas em termos de suporte pessoal, articulação de atividades dentro e fora da cadeia, e vitimização. Enfim, além dos danos causados pela organização formal, os padrões de vitimização interpessoal ${ }^{11}$ e grupal são estruturados por essas três modalidades de organização informal dos presos (Figura 1).

FIGURA 1

Vitimização prisional

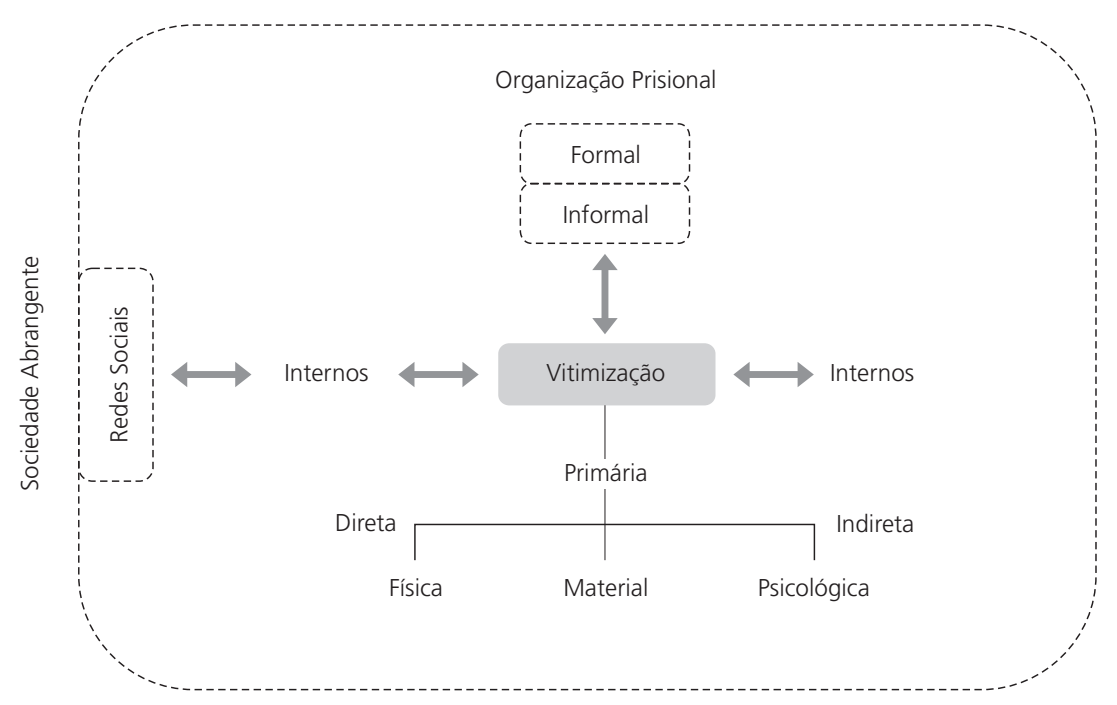

Padrões de agressão interpessoal e grupal

Física

A miríade de agressões físicas, que atinge de modo visível ou não os corpos dos encarcerados, revela a importância de formas expressivas e instrumentais, assim como a combinação de padrões difusos e concentrados de violência ligados aos arranjos de cadeia e às quadrilhas, respectivamente.

Começando pelas formas de violência difusa e expressiva, os episódios de violência sexual $(2,9 \%)$ não estão entre os mais frequentes (cf. Edgar, O’Donnell e Martin, 2003; Wolff e Shi, 2011), por causa da subdeclaração, mas ilustram as virtualidades negativas extremas do cárcere. Apesar da fartura de sexo, pago ou não pago, proporcionada pelas visitas íntimas, essa violência expressiva (cf. Chambliss, 1967; Cohn e Rotton, 2003), típica 
dos arranjos de cadeia, continua na ordem do dia como um modo de fazer gênero, deslocar a frustração ou compensar a masculinidade malsucedida (cf. Jefferson, 2002), encarcerada.

Já tinha ouvido falar que acontecia tijolada, tacada, limusine... Limusine é mais de dez homens pegarem um pobre coitado nu, abrir as pernas e sair pela cadeia toda com ele pendurado naquela situação e todo mundo dando dedada. Me espantou muito ver um homem passando por aquela situação (Interno, 32[b] anos).

Os alvos são os acusados ou condenados por delitos sexuais. Afora eles, os internos novatos, como um estrangeiro preso certo tempo atrás por tráfico internacional de drogas ou outro com transtornos mentais, também são vítimas preferenciais, sem que eles se sintam à vontade para falar sobre isso, a exemplo de três presos que assumiram, com dificuldade, ter passado por essa experiência devastadora. $\mathrm{O}$ aprisionamento da dor no silêncio estéril, o encarceramento da voz da vítima, expóe o requinte de crueldade desse rito de socialização ou "prisionização" (cf. Sykes, 1958). Entretanto, a raiva misturada com a impotência gera entre esses internos uma autovitimização específica que consiste em automutilaçôes via cortes no braço e no tórax (Funcionário, 47 anos).

Entre as formas aparentemente difusas e instrumentais, as menos reportadas - murros $(5,8 \%)$, queimaduras $(4,8 \%)$, eletrochoque/tortura $(2,9 \%)$ - exibem as marcas do aprisionamento e da engenhosidade para mortificar: "Já sofri queimadura de água quente, [de] garrafa plástica; eles esquentam a garrafa e saem pingando pelo corpo" (Interno, 31[d] anos). Como sói acontecer, conflitos miúdos, que seriam facilmente sanados em outras situaçōes, são exacerbados pelo confinamento e desembocam em atrocidades: "Solicitaram-me um atendimento a um interno que 'jogou água quente no ouvido' e eles acham que foi um colega de cela que fez isso para que saísse de lá quando estava com visitas" (Almeida, 2007-2011, 16/10/2008).

Seguindo um padrão claramente concentrado, os castigos por dívidas de drogas, semelhantes aos do extramuros, visam à penalização pelo sofrimento e à subjugação do outro, assim como a dissuasão dos mesmos comportamentos entre os demais: "Um cara que pegou três pedras [crack] e não pagou ia morrer com uma serpentina [instrumento para esquentar água] na boca” (Interno, 34[b] anos). Do mesmo modo, as retaliações e contrarretaliações, que tanto elevam os níveis de vitimização entre delinquentes, também estão representadas: "Sofri pouca coisa; fui esmurrado por causa de um problema 
que um cara tinha com meu irmão. Aí eu disse que se fosse lá fora eu queria ver" (Interno, 34[a] anos). Daí também o ressentimento, a motivação para se vingar e a realimentação do ciclo de retaliaçôes: "Me deram tijolada, choque... É difícil de esquecer... Mas foi só na chegada mesmo. Depois, como o cara 'tira a cadeia' [cumpre a pena], eles esquecem. Quem apanha sempre lembra; quem bate, esquece. Já vi acontecer outras coisas piores com pessoas desse artigo... assédio..." (Interno, 24[c] anos).

Quanto às modalidades mais frequentes de agressão física - o espancamento $(52,4 \%)$ e as perfuraçōes e cortes $(19,5 \%)$-, elas são chamadas de "covardia" por mobilizarem vários contra um, reduzindo as chances de defesa do alvo e diluindo a responsabilidade individual dos autores. Elas evidenciam igualmente a agência e a hierarquia interna das quadrilhas e dos arranjos de cadeia, pois costumam ser iniciadas pelo líder e em seguida transferidas para os demais. Contudo, em sintonia com o estilo vigente de gerenciamento da violência, os agressores evitam deixar, mediante técnicas simples, marcas visíveis, para não chamar a atenção dos funcionários.

Eles me espancaram com pedra. Eles colocam pedra enrolada na calça, aí amarram a boca da calça pra não ferir o corpo da pessoa, para não demonstrar que está sangrando; aí bate na pessoa nas costas, no peito. Aí teve um abençoado que mandou parar, pois eu ia morrer. Um outro me deu assistência, me deu leite (Interno, 44[a] anos).

TABELA 3

Formas e prevalência de vitimização fisica

\begin{tabular}{l|l}
\hline \multicolumn{1}{c|}{ MODALIDADE } & \multicolumn{2}{|c}{$\%$} \\
\hline Tortura/eletrochoque & 2,9 \\
Violência sexual & 2,9 \\
Queimaduras & 4,8 \\
Murros & 5,8 \\
Execuções & 11,7 \\
Perfurações e cortes & 19,5 \\
Espancamento & 52,4 \\
\hline TOTAL & 100,0 \\
\hline \hline
\end{tabular}

As execuções $(11,7 \%)$ incluem os eventos que tiveram esse objetivo inicial e foram exitosos em seu intento. Realizadas pelos internos, mas não necessariamente arquitetadas por eles, são menos frequentes na atualidade porque despertam atenção e geram sanções disciplinares. As motivações são pouco confessadas, mas em vários casos foram identificadas motivações ins- 
trumentais, como estratégias de controle de mercados de drogas, retaliações encomendadas de fora do cárcere e sanções pela quebra de regras prisionais. Coerente com o gerenciamento da violência pelas quadrilhas, várias execuções simulam suicídios com o intuito de dificultar a investigação. Vale lembrar o caso de um sentenciado por estupro, com repercussão na mídia, que ao sair, graças ao indulto de Natal, reincidiu e, ao retornar à prisão, teria se matado. Informalmente, porém, soube-se que ele "foi suicidado" por prejudicar os que cumpriam pena pelo mesmo crime e aguardavam idêntico benefício.

\section{Material}

A subtração compulsória de bens e valores escassos (35,6\%) mostra a tendência das quadrilhas a concentrarem a violência, as oportunidades de rapinagem e a cobrança de renda de proteção.

Essa subtração envolve roubo, furto, exploração e extorsão (Tabela 4). Os alvos podem ser tanto os hipossuficientes, como aqueles que têm recursos financeiros, mas que não possuindo capital social para evitá-la também representam oportunidades de capitalização para os predadores de plantão. $\mathrm{O}$ furto ( $16 \%)$ e o roubo (12\%) são menos relatados e, de fato, ocorrem menos do que as outras modalidades porque provocam confusão e intervenção dos funcionários, o que não interessa a ninguém. Em contraste, a exploração (28\%) e a extorsão (44\%) são mais frequentes porque são mais lucrativas e silenciosas. A exploração implica abusos financeiros como cobrança de taxas, pagamento de celas e de serviços fornecidos pela instituição - mas apropriados e comercializados pelos presos - e o não pagamento adequado por serviços prestados.

Os presos [que trabalham nas oficinas] são obrigados a entregar metade do que recebem ao líder, sob pena de represália. Um dos internos se recusou a entregar o dinheiro porque estava com dificuldades na família e teve que "passar o portão" [se transferir para outro pavilhão] (Almeida, 2007-2011, 20/3/2009).

TABELA 4

Distribuição das formas de vitimização material

\begin{tabular}{l|l}
\hline \multicolumn{1}{c|}{ CATEGORIA } & $\%$ \\
\hline Roubo & 12,0 \\
Furto & 16,0 \\
Exploração & 28,0 \\
Extorsão & 44,0 \\
\hline \hline
\end{tabular}


A extorsão, tida como a essência da vitimização prisional (cf. Edgar, O'Donnell e Martin, 2003), envolve ameaças, agressōes físicas, confinamento forçado e pagamento de resgates. $\mathrm{O}$ irônico e cruel confinamento nas celas de quem já está preso mostra o quanto a cadeia está conectada com a sociedade abrangente, onde igualmente têm prosperado formas de privação de liberdade de pessoas para a consumação desse tipo de delito. Tal como várias outras atividades rendosas, a extorsão é praticada pelas quadrilhas com a ajuda de comparsas do extramuros. Mal chegam nas unidades, os internos já são esquadrinhados para identificar os delitos por eles cometidos, saber se contam com recursos próprios (ou de terceiros) e calibrar a pressão sobre eles e suas famílias (cf. Best, 1982).

O elevado percentual de extorsōes de presos oriundos, na sua maioria, das classes populares revela a rapacidade dos autores. Se assaltantes de banco - considerados a elite da cadeia - recém-ingressos e ainda não enturmados com seu grupo parecem dispor de dinheiro fácil, outros internos pedem a seus familiares para se cotizarem para os resgates, gastando suas míseras economias ou tomando empréstimos. Por sua vez, presos remediados chegam a vender seus instrumentos de trabalho, carros e imóveis, para pagá-los e não sofrer sanções, como a expulsão do pavilhão, como veremos a seguir. Enfim, essa predação dilapida o patrimônio dos poucos que têm alguma coisa ou juntaram dinheiro com o crime e agrava a miséria da maioria que não saiu do fundo do poço social.

Eles extorquem, eles fazem até as pessoas de reféns dentro da cadeia mesmo. Aí tem preso que tem que vender o que tem, a casa, o carro. Tinha um cara que tinha um caminhão que estava avaliado em mais ou menos, acho que era 60 mil ou era 40 , e ele teve que vender por 20 ou foi 30 para depositar o dinheiro na conta da quadrilha X, senão... (Interno, 39[a] anos).

Eu respondo a assalto a banco e eles acham que quem faz assalto a banco tem dinheiro. Me colocaram certa vez numa cela e disseram que eu tinha trinta minutos para depositar 7 mil reais numa conta (Interno, 31[d] anos).

\section{Psicológica}

As pressões psicológicas $(29,2 \%)$ também repartem-se entre formas difusas e concentradas, expressivas e instrumentais, que estressam, desestabilizam e aumentam a insegurança quanto aos papéis desempenhados 
pelos alvos nos seus grupos de referência. Elas se traduzem em humilhação, bullying (cf. Nagi, Browne e Blake, 2006), exclusão do convívio, ameaças e expulsão dos pavilhões.

A humilhação é bastante associada ao desempenho das atividades de lavagem de pratos, limpeza das celas e coleta de dejetos. Apesar de essenciais, o componente poluente dessas tarefas faz com que elas sejam transferidas, de modo humilhante, para novatos que, não possuindo meios para negociá-las, percebem-se como "escravos". Nessa linha, o bullying praticado igualmente contra os recém-ingressos, por um ou mais detentos, assume as formas da "sugesta" e da "ladainha". Enquanto a sugesta remete à provocação pontual, em voz baixa, a ladainha consiste em provocações e sacanagens continuadas e em alta voz, para "apertar a mente", tensionar e amedrontar: "Sofri o que eles chamam de 'apertar a mente'. Aquela coisa de ficar zoando, falando coisa pra deixar a pessoa tensa, para deixar o cara que nunca foi preso, primário amedrontado" (Interno, 31[e] anos). Apesar das particularidades do bullying prisional, como a quase impossibilidade de defesa por parte dos alvos, as evidências mostram que ele também é uma forma privilegiada de fazer gênero, de construir masculinidade (cf. Jefferson, 2002).

Tão cruel como isso é a exclusão do convívio ou "encurralamento", no qual o interno é isolado dos demais, perde a já diminuta mobilidade e é impedido de fazer coisas essenciais: alimentação, uso do sanitário e acesso ao serviço de saúde.

Encurralação é a proibição de você fazer tudo. Você não tem direito a nada e tem que respeitar o direito que você não tem. Você não pode fazer nada do que você quer, só o que eles querem. É você sentir vontade de ir no banheiro, aí vem o outro e diz "não! Quem vai no banheiro agora sou eu”. É você querer pegar uma garrafa d'água e o cara não deixar você pegar. A pessoa faz isso por ignorância ou como um modo de exercer poder. É como dizer "eu sou eu e você é o cocô do cavalo do bandido" (Interno, 36[a] anos).

As ameaças insinuam ou explicitam a possibilidade de o preso vir a ser atingido, criando a expectativa inquietante de um dano posterior e de busca de proteção: "Queriam me pegar aí no pavilhão quando eu cheguei porque achavam que eu era de outra facção [quadrilha]. Tem gente lá com marcas de faca nas costas, facãozada. Mas eu só sofri ameaças" (Interno, 42[b] anos). Um risco preocupante é a expulsão do pavilhão ou "passar o portão". Os internos que cavaram, após várias transferências traumáticas de unidade 
prisional, um nicho mais ou menos protegido ao se desentenderem com seus colegas - por recusarem pagar extorsão ou guardar drogas, celulares e armas - tornam-se personae non grata. Disso decorrem agressōes que podem culminar, com a mediação dos funcionários ou a aquiescência da vítima, na expulsão desta. Daí para frente e abalado psicologicamente, o interno investirá em uma custosa e arriscada adaptação a um novo pavilhão, a qual poderá redundar, em caso de insucesso, em novos agravos.

Indireta

Como parte dessa atmosfera acachapante, os internos estão expostos aos sofrimentos infligidos aos conhecidos, pessoas significativas ou mais chegadas, como colegas e familiares. No caso dos colegas e dependendo da proximidade física e social, tais agressōes indiretas $(4,7 \%)$ são piores do que as sofridas na pele. As evidências são os sentimentos de medo, impotência, ansiedade e hipervigilância, principalmente entre presos sem trajetória criminosa anterior.

Enquanto a ansiedade e o medo de sofrer ataques parecidos estão presentes em todos os relatos, a impotência, mesclada com a culpa, é evocada pelos que possuíam vínculos afetivos com os alvos diretos e não puderam socorrê-los: "Já vi gente morta nos meus pés, coisa que a gente não pode fazer nada. Teve um amigo que me ajudava muito e morreu aqui” (Interno, 32[c] anos). Dada a conjunção entre insegurança objetiva e subjetiva - pelas restrições espaciais, materiais e logísticas (cf. Chubaty, 2001), previsibilidade de lugares e tempos, e dificuldades de fuga ou oposição -, parte dessa ansiedade é deslocada para a formação de defesas psíquicas que, a exemplo do autoisolamento e da hipervigilância, são inócuas ou contraproducentes.

Eu já vi muita gente sair despedaçada. Mais de cinquenta atacando um, rola madeira, pau, banco; é muito assustador. Já pensou eu sair todo deformado? Então fico pensando que eu não posso vacilar. Estou ficando muito nervoso, pois eu vigio muito até na própria cela (Interno, 36[a] anos).

Outras atribulaçôes decorrem dos impactos desse enredo de vergonha, estigmatização e fracasso social sobre as famílias. Primeiro, ao lado da falta de supervisão sobre coisas importantes, há um controle vexatório das visitas. Segundo, falta qualquer suporte para as famílias, especialmente aquelas oriundas de regiōes distantes do estado que perderam, com a prisão do pa- 
rente, seu provedor e passam por dificuldades. Afora isso, o medo constante, os pagamentos de extorsões e dívidas etc. por parte dos familiares engrossam o caldo de provaçôes dessa gente.

Fatores da vulnerabilidade

A exposição ao risco é uma característica crônica do estabelecimento prisional que contribui para a conformação de práticas sociais e modalidades de agressão e fragilização de grande parte dos internos. Uma complexa inter-relação entre ambiente de risco, poder, vulnerabilidade e estratégias individuais e de grupos condiciona a vitimização potencial. Em outros termos, a vulnerabilidade ou a probabilidade de ser agredido varia de acordo com cinco fatores sociorganizacionais: o status de novato, o poder aquisitivo, as dívidas, a resistência às regras prisionais e o pertencimento aos grupos criminosos (Tabela 5).

TABELA 5

Fatores da vulnerabilidade dos internos

\begin{tabular}{l|l}
\hline \multicolumn{1}{c|}{ CATEGORIA } & $\%$ \\
\hline Status de novato & 5,1 \\
Dívidas & 14,4 \\
Poder aquisitivo & 21,8 \\
Pertencimento às quadrilhas & 28,9 \\
Resistência às regras prisionais & 29,8 \\
\hline
\end{tabular}

Imbricado com os demais fatores da vulnerabilidade, o status de novato $(5,1 \%)$ está no foco das práticas de socialização ou "prisionização" que, semelhantes aos ritos de passagem, visam ao despojamento da identidade pregressa e à inculcação do habitus institucional (cf. Paes-Machado e Albuquerque, 2006). Só que neste caso o rito se duplica e se bifurca: os sujeitos são socializados nos domínios igualmente brutais da organização formal e informal do estabelecimento. É assim que, em oposição ao veterano ou "cadeeiro", o status de novato implica, na maior parte das vezes, pouca ou nenhuma disponibilidade de capital social para se defender dos abusos associados a esses ritos. Ironicamente, contudo, chegará o tempo em que eles mudarão de lado e aplicarão, com o empenho esperado dos veteranos, os mesmos trotes nas novas levas de recém-chegados (cf. Idem, ibidem). 
Quando a gente chega na cadeia a gente é testado de várias formas para ver nosso temperamento, se a gente é humilde ou se é arrogante. Quando você chega os caras pedem algo emprestado, aí você empresta e eles não devolvem. Se você chegou, é novato, é otário. Aí depois vai aumentando, passa para a força física ou coisa pior (Interno, 20[b] anos).

O poder aquisitivo concorre para 21,8\% da vulnerabilidade dos presos. Tamanha influência do capital econômico nas chances de ser agredido demonstra as enormes, mas pouco lembradas, semelhanças entre os valores internos e externos ao cárcere com respeito ao dinheiro e outros fatores de desigualdade social e à impunidade.

Estamos no mundo da corrupção, do dinheiro e da hierarquia. Se eu tivesse condição eu estaria em um espaço maior, melhor, mas eu fico em um espaço menor e humilhado. Aqui há muito preconceito em relação ao negro e ao pobre. O que vale aqui é o dinheiro e ninguém muda isso aqui (Interno, 26[c] anos).

Sob essa perspectiva, o interno oriundo do interior ou da zona rural do estado - conhecido como "jacu” - é um alvo fácil pela falta de recursos para se proteger. Quase um terço dos presos $(27,4 \%)$ está nessa situação, sem suporte familiar e institucional, e, nesse mundo tão desigual, discriminados pelos pares. Ao lado dos jacus, estão os "couros de ratos" e "fariseus", que caíram no funil do sistema por delitos menores, com baixo poder aquisitivo, sem visitas, nem ajuda de parentes - um atributo de status e fator de proteção -, e que ao ingressarem na prisão tampouco podem contrabalançar suas desvantagens: "Quem mais sofre na cadeia são os couros de ratos. Pessoa que não tem ninguém por ele; às vezes quem vem de fora. Me recordo de um rapaz que morreu porque xingou um cara" (Interno, 25[a] anos). Ademais, nesse grupo estão os internos que desenvolvem enfermidades físicas ou psíquicas, tornando-se dependentes de cuidados adicionais do estabelecimento e presas fáceis dos colegas.

Também na confluência da falta de capital econômico e da vulnerabilidade, as dívidas contraídas por compras de gêneros alimentícios, produtos de higiene e drogas - consumidas por 52\% dos entrevistados - influenciam em $14,4 \%$ nas chances de ser agredido. Se as quadrilhas facilitam essas compras, elas são implacáveis com respeito aos atrasos dos pagamentos, seja pela importância do dinheiro nesse mundo de escassez, seja pela necessidade de manterem a reputação: "Nunca vi um real ter tanto valor como tem na 
cadeia. Um real na cadeia é ouro. Se o cara passa duas ou três visitas [da família] sem pagar a dívida de um real, já era. A liderança da cadeia nunca aceita dívida de droga. Quando não paga, paga com sangue" (Interno, $33[\mathrm{e}]$ anos).

Dados os incentivos para afogar a amargura e buscar distração nas drogas, uma das piores coisas é usar essas substâncias sem ter como pagá-las: "Aqui só pode usar droga quem tem dinheiro, para não sofrer retaliação. Quem tem dívidas e não tem condiçôes de pagar, sofre, como muitos que chegam no Serviço Médico, todos machucados" (Interno, 30[g] anos). Uma alternativa possível para alguns é a ajuda da família, como vimos nas extorsões, para evitar represálias.

Tem mãe, pai que toma dinheiro emprestado para colocar em uma conta para pagar o débito do filho. Às vezes a gente sabe que é por questão de droga, às vezes é dívida [...] para comprar lanche. Mas tem outras coisas que eles não revelam por medo de represália. E não era dinheiro pouco não. Traziam o dinheiro porque senão o interno iria morrer (Funcionário, 52[a] anos).

Além de castigos físicos, os inadimplentes podem converter-se em serviçais ou "laranjas", assumindo culpas de terceiros como a posse de drogas, celulares e armas artesanais descobertos em revistas das celas. Há também os que chegam a disponibilizar, dentro de mais um efeito colateral das visitas íntimas e da onda de vitimização prisional (inmate victimization wave), o corpo das esposas, irmãs e filhas para seus impiedosos credores.

Lembro de uma ocasião em que vi um interno na porta da cela sentado, com a cabeça baixa, e uma fila de quase vinte homens que entrava e saía da cela onde estava sua mulher. Quando terminou, a mulher saiu aos prantos e nunca mais retornou. Soube depois que ele entregou a mulher dele para manter relaçôes sexuais com outros internos devido a dívidas contraídas na prisão (Funcionário, 52[a] anos).

Em contraste com os conhecimentos - disposiçóes e credenciais - que qualificam o capital cultural na sociedade abrangente, na cadeia esse capital remete à interiorização das normas e regras que constituem, destoando da visão do senso comum da prisão como estado de natureza, a ordem social dos cativos. Dessa perspectiva, a resistência a essas regras contribui para 29,8\% da vulnerabilidade dos internos. Tais regras são ansiógenas e capilares. Sua interiorização supõe um autocontrole pessoal maior do que estavam acostumados 
no mundo menos vigiado do extramuros. Como na sociedade de corte (cf. Elias, 1987), essa aprendizagem envolve o disciplinamento das emoções e impulsos imediatos, a arte da simulação e dissimulação de atitudes e condutas, o que é mais uma contribuição inestimável do cárcere para o aperfeiçoamento das habilidades delitivas.

Garantidas pela organização informal dos internos e não por nenhuma instituição total goffmaniana, essas regras versam sobre todas ou quase todas as transações internas e externas, limitando ao extremo a liberdade, a iniciativa e a comunicação individuais, como conversas, cartas e telefonemas.

O que eu não suporto é não poder chegar no portão para reivindicar um direito.

Tem que estar presente sempre com um deles [membro de um grupo criminoso].

O mais rigoroso lá é a comunicação, pois tudo tem que ser passado por eles. Fica um no portão que é mais rigoroso do que um agente [penitenciário]. Cada cela e galeria tem um responsável. Se está acontecendo algo naquela cela, o responsável tem que falar com o líder porque se ele não falar e outra pessoa falar, ele recebe punição (Interno, 39[a] anos).

Se uma parte dessas regras condensa o bom senso, as precauções e o corporativismo dos arranjos de cadeia, a outra parte reflete, como temos visto, as estratégias de concentração das oportunidades econômicas ilícitas, controle sobre armas e celulares (cf. Paes-Machado e Riccio-Oliveira, 2009), e gerenciamento da violência por parte das quadrilhas. Entre os exemplos do primeiro tipo estão o respeito às visitas - que inclui não criar problemas, não olhar para os visitantes e não andar sem camisa nos dias em que elas ocorrem -, a restrição de contatos com os funcionários e o sigilo acerca dos bastidores da prisão. O segundo tipo de regra, por sua vez, envolve a proibição da venda de drogas, da posse de armas e celulares sem permissão dos líderes ou dos “donos da cadeia”. Nessa linha, está a interdição de matar ("não sangrar") sem autorização e o acatamento das prescrições, igualmente estabelecidas pelos donos da cadeia, relativas aos modos, lugares e momentos certos das execuções. Enfim, no caso dos grupos delituosos religiosos, ainda há a participação obrigatória em rituais de oração e jejum que reafirmam normas ideais e reforçam a coesão coletiva.

Ora, conquanto as sançôes pelo seu descumprimento sejam severas e os infratores não possuam defesas apropriadas, elas não formam um todo monolítico. Além de se desdobrarem em outras regras e sançôes, a sua aplicação varia de acordo, por um lado, com os traços pessoais das lideranças, 
a composição e as relações de poder nos pavilhões, e, por outro, com os laços sociais, tempo de cadeia, modo de agir ou "proceder" dos presos (cf. Ramalho, 2002).

Quem são os rebeldes que quebram essas leis não escritas e, agora também, dentro do redirecionamento da violência pelas quadrilhas, escritas em prospectos distribuídos aos presos? Eles são desviantes do mundo institucionalizado do desvio porque não compartilham seus sentimentos, valores e condutas, nem temem suas sançôes. Entre eles estão os novatos desavisados e ressentidos, os individualistas contumazes, os empreendedores que atuam à revelia dos donos da cadeia, os transtornados mentais, os que vieram das caóticas instituições de menores ou das ruas e os inconformados com a pena.

Já pensei em acabar com minha vida e já dei muito trabalho porque eu não me conformava com essa condenação de 25 anos. Já apanhei muito, pois eu fazia muita besteira, mas é porque eu ficava revoltado... É muita revolta ficar preso aqui dentro sem dever... Perdi muita coisa (Interno, 31[f] anos).

Tão ou mais importante do que os capitais econômico e cultural são os laços sociais - "conhecimentos" e "consideração" - com o submundo criminoso. Tal como na sociedade abrangente, os investimentos na obtenção e multiplicação desse capital são o fulcro da existência, pois ele garante a inserção e a reprodução social, assim como a defesa contra ataques (cf. Paes-Machado e Riccio-Oliveira, 2009). Efetivamente, a posse desse capital faz toda diferença nesse mundo movediço, mas ainda assim altamente regulado e hierarquizado: "Aqueles que não são conhecidos dos demais ficam mais tempo na observação - cerca de oito dias -, enquanto aqueles que têm conhecidos no sistema ficam em torno de 24 horas e normalmente são convidados para um pavilhão" (Almeida, 2007-2011, 14/4/2009). Esses laços têm primazia, em vários aspectos, sobre o capital econômico, uma vez que sem eles até os internos remediados e abonados se arriscam, como vimos, a ser depenados. Mesmo nos casos de familiares que se dispõem a pagar pela proteção do parente, é preciso fazer acertos prévios com os líderes dos grupos delituosos, o que mais uma vez confirma a relevância desse capital.

Apesar, ou por causa, de essas quadrilhas serem perpetradoras e, inversamente, protetoras, seus integrantes experimentam agressões ocasionadas pelo déficit interno de confiança e disputas com as quadrilhas rivais. Ou seja, em contraste com a solidez do capital social derivado de domínios estáveis e da sobreposição de vínculos (cf. Coleman, 1988), os laços de pertencimento em 
questão caracterizam-se pela volatilidade. Daí que eles possuam mais implicaçôes negativas para essa vulnerabilidade $(28,9 \%)$ do que outros. Afinal de contas, muitos são atraídos pelos seus líderes, discípulos aplicados da cartilha neoliberal do sucesso a qualquer preço, papéis modelos ou "espelhos" no mundo do crime. Os internos que ingressam nessas quadrilhas como "soldados" são os já mencionados "fariseus" e "couros de ratos" que compensam sua vulnerabilidade e saem do anonimato ao empreender uma trajetória de ascensão nesse submundo institucional. Vir a ser membro dessas organizações empodera o indivíduo e o convida ao esforço, o que é o mesmo que retomar saúde mental, superar fracasso e embolsar créditos de proteção (cf. Paes-Machado e Riccio-Oliveira, 2009). Aos poucos, sem saída, cada interno construirá uma nova identidade a partir da inserção em um subgrupo, estabelecendo identificação com este e restaurando relaçōes com antigos rivais. Para se integrar terá que superar rivalidades, sanar arestas e redimensionar conflitos. A identificação com seu grupo de interesse (endogrupo) desencadeia fenômenos intergrupais que distorcem sua percepção, levando-o a hiperdimensionar negativamente as características do exogrupo, agora percebido como homogêneo, coeso e hostil (cf. Myers e Lammer, 1976).

Tais laços de pertença, se sabe, são situacionais e ambivalentes. Tudo vai bem quando os líderes estão no auge, os ajudantes e os soldados cumprem suas obrigaçôes, e todos estão à vontade nos módulos por eles comandados. Tudo fica mal quando as lideranças perdem poder, os subalternos caem em desgraça e uns e outros precisam ser deslocados para unidades (ou pavilhóes) controladas por grupos rivais que, conhecedores do seu pertencimento, infernizarão suas vidas. Por isso, não é fortuito que, recusando direitos, muitos não queiram o benefício da progressão de regime, necessariamente acompanhado por deslocamentos de unidade. Por conseguinte, esses deslocamentos são cercados de cuidados por parte dos funcionários.

Sempre fui perseguido. Me envolvia com certos tipos na cadeia e você fica malvisto, né? Aí vai pra um pavilhão, não dá certo; vai pra outro pavilhão e também não dá certo... Você passa um tempo no pavilhão depois sofre ataque: cacetada, "panada" de faca... Estou desse jeito aqui [com hematomas]. Eu era de outro sistema [quadrilha X]; depois fui pra outro pavilhão, mas não deu certo (Interno, 28[b] anos).

Em outros casos, a vulnerabilidade é fruto do sucesso alcançado. Entre a bajulação e o despeito dos pares, não é raro que o status de ajudantes ou "braços direitos" dos líderes suba às cabeças dos sujeitos. Estes passam a co- 
meter abusos, solapar a autoridade ou tentar tomar o lugar dos seus "patrōes". Quando seus planos fracassam, só lhes resta a morte feia, confirmadora da reputação violenta do superior hierárquico. Uma ilustração emblemática é a morte acompanhada pelo corte brutal do rosto para indicar a perda da face e o desmascaramento da traição.

Com o cara que morreu aí foi uma barbaridade terrível. Essa parte do rosto foi cortada de fora a fora... quis pegar uma mulher de preso. Tem gente que, às vezes, ganha uma patente de xerife na cadeia e abusa daquilo, acha que é o dono do presídio (Interno, 36[a] anos).

Esse que morreu essa semana morreu feio. Mas ele estava extorquindo, massacrou muita gente. Há dez dias agora, ele mandou matar um cara de fulano [nome do líder da organização] na rua, e este, quando foi [transferido] pro outro estado, advertiu que ficasse de olho nele porque ele tava com um plano diferente. Ele pensava que não ia ser descoberto (Interno, 39[a] anos).

Novamente, os sobreviventes e desafetos enfrentam a situação desesperadora de não poderem permanecer, nem mudar de unidade, o que é mais uma demonstração do controle territorial do sistema prisional, do acirramento das relações concorrenciais e da escalada de violência entre as quadrilhas de internos.

Aqui tem muitos que não podem ir para aquela unidade. Tem pessoas que saíram daqui e foram pra lá, que não estão podendo se juntar com ninguém, porque ninguém quer. Tem pessoa que está saindo e não tem mais coragem de retornar porque está ameaçada pelo próprio colega. Aí ele não tem mais coragem de voltar, pois podem tirar a vida dele (Interno, 38[a] anos).

\section{Conclusão}

Conquanto a prisão esteja associada, desde há muito, à violência que nela floresce, essa relação é dinâmica, transiente, temporal e espacialmente contextualizada. Sob esse prisma, para explicar a produção, a repetição e a mutação dos padrões de agressão prisional é preciso considerar os nexos existentes entre os níveis de violência da sociedade abrangente (cf. Byrne, Hummer e Taxman, 2007), as características da organização formal e informal dos estabelecimentos (cf. Idem, ibidem) e a dinâmica dos conflitos 
(cf. Edgar, O’Donnell e Martin, 2003) entre os seres sofridos que povoam o cárcere.

As abundantes evidências acerca da estrutura e dinâmica de funcionamento da prisão esclarecem seu significado moral (cf. Birkbeck, 2010) como o lugar daqueles que, vistos como desprovidos de humanidade (cf. Misse, 2011), devem ser não apenas privados de liberdade, mas brutalizados. Nesse plano da negação de direitos da pessoa presa, não resta dúvidas sobre a responsabilidade do Estado pelos danos (cf. Ward, 2004) - materiais, físicos e psicológicos - causados aos custodiados. Embora não sejam referidos pela literatura internacional (cf. Edgar, O’Donnell e Martin, 2003; Wolff et al., 2007), esses danos contribuem, no contexto aqui analisado, para um índice de vitimização de $54,3 \%$, que é mais do que o dobro do da população em geral.

Ao tempo que a mobilização dos recursos, da tecnologia e da mentalidade da sobrepenalização reduz a legitimidade da pena (cf. Chubaty, 2001) e arruína as possibilidades, se é que estas existem, de construção de novos sentidos positivos de vida, ela força os presos a se virarem, exercerem poder via arranjos de cadeia e aceitarem, apesar das resistências, a governança das quadrilhas. Desse ponto de vista, mesmo que a prisão seja uma instituição do Estado, este é apenas coadjuvante na cena microssocial, enquanto o poder desses grupos é o protagonista que ganha os prêmios: é ele o promotor da energia estática que vigora, impera e ameaça. $\mathrm{O}$ Estado fica então com a gestão da casa; o crime, o vencedor, com a instituição do lar. É deste que brota a trama instituinte com seus dispositivos que afetam a integridade dos presos. É assim que, reencenando, ironicamente, a ontogênese do Estado ou da concentração dos meios de força, mas desta vez dentro de estabelecimentos formalmente controlados por aquele, as quadrilhas modulam e catalisam a vitimização, minimizando e maximizando danos institucionais e interpessoais.

Nessa grande câmara de vitimização, os elevados índices de agressão material (35,6\%), física $(37,3 \%)$ e psicológica $(29,2 \%)$ refletem a valorização da violência, a exacerbação de conflitos mesquinhos e a frustração da masculinidade entre os internos. Enquanto uma parte dessas agressões, a exemplo do bullying, dos estupros de novatos e das agressões físicas pontuais, está conectada com a violência difusa, instrumental e expressiva dos arranjos de cadeia, a outra parte deriva da violência concentrada e instrumental das quadrilhas (cf. Chambliss, 1967; Cohn e Rotton, 2003): primeiramente, a concentração e o gerenciamento das decisões e modalidades de agressões físicas e execuções; segundo, a extorsão pontual e continuada com a participação de comparsas 
do extramuros; terceiro, a exploração de serviços, a imposição de taxas e a cobrança de dívidas por compras de bens, permitidos ou contrabandeados, acompanhadas por puniçôes dos recalcitrantes e devedores; por fim, a escalada de retaliaçôes e contrarretaliações violentas entre esses grupos.

Por outro lado, perpassando os fatores de vulnerabilidade - como o status de novato, o poder aquisitivo, o endividamento, a resistência às regras prisionais e o pertencimento às quadrilhas -, a disponibilidade de capital social faz diferença, pois atenua, tal como em outros domínios, restrições ligadas àqueles fatores. Sem esse capital, tais fatores seriam menos suportáveis pelos presos. Entretanto, o mesmo não se aplica inteiramente aos laços de pertença às quadrilhas prisionais. Como vimos, estas convocam, empoderam e protegem aqueles que caíram nos porões do sistema de justiça criminal, mas aumentam as chances de eles sofrerem agressões derivadas do déficit crônico de confiança e do acirramento das suas relaçóes concorrenciais mútuas. Entre as provas disso estão os riscos associados com as transferências de pavilhões e unidades.

Por essas razões, não é exagero afirmar que as quadrilhas vêm reinventando a prisão e requalificando a violência entre os internos. Se o populismo punitivo e, associado a este, a política de guerra às drogas infundiram um novo sentido, de cima para baixo, nessa decrépita e desacreditada instituição (cf. Garland, 2001), no caso da prisão em tela e de outras prisões brasileiras, a mudança igualmente decorre do empreendedorismo violento, das estratégias e práticas visando à acumulação de recursos que são implementadas de baixo para cima pelas quadrilhas criminosas.

Com respeito às redes familiares, o apoio aos internos é o caminho mais curto para elas serem impactadas pela violência prisional. Esses efeitos - para trás e para frente, para dentro e para fora do cárcere - foram denominados de ondas de vitimização prisional. Sob esse ângulo, a prisão tanto reflete (cf. Stowell e Byrne, 2007), quanto espirra violência na sociedade abrangente. Por fim, o drama da vitimização dos internos é uma chave para compreender a dinâmica de um sistema prisional mais distópico do que podemos imaginar.

Referências Bibliográficas

Aguirre, Carlos. (2009), “Cárcere e sociedade na América Latina: 1800-1940”. In: Maia, Clarisse Nunes, Sá Neto, Flávio de, Costa, Marcos \& Bretas, Marcos Luiz (orgs.). História das prisões no Brasil. Rio de Janeiro, Rocco, vol. 2. 
ALMEIDA, Odilza Lines de. (2007-2011), "Diários de campo: registros não publicados das notas de campo de pesquisa". Salvador.

(2011), Sem lugar pra correr nem se esconder: um estudo de vitimização no sistema penal baiano. Salvador, Bahia, tese de doutorado, Programa de Instituto de Saúde Coletiva, UFBA.

Alvarez, Marcos César. (2008), "Os sentidos da punição”. Com Ciência, 98. Disponível em <http://www.comciencia.br/comciencia/?section=8\&edicao=35\&id=417>, consultado em 15/12/2010.

BEST, Joel. (1982), "Crime as strategic interaction: the social organization of extortion”. Journal of Contemporary Ethnography, 11, pp. 107-128.

BIRKBECK, Christopher. (2010), "Prisiones y internados: una comparación de los establecimientos penales en América del Norte y América Latina”. Caderno CRH, 23 (58): 129-149.

BORGES, Doriam. (2008), "Vitimização criminal: prevalência, incidência e o estilo de vida". In: DuARTe, Mário Sérgio de Brito (coord.). Pesquisa de condiçōes de vida e vitimização de 2007. Rio de Janeiro, Riosegurança.

Bourdieu, Pierre. (1989), O poder simbólico. Rio de Janeiro/Lisboa, Difel/Bertrand.

BRASIL. Ministério da Justiça/Depen. Sistema Nacional de Informaçôes Penitenciárias - InfoPen. (2011), Dados consolidados. Brasília.

Byrne, James Michael \& Hummer, Donald. (2007), "Examining the impact of institutional culture on prison violence and disorder: an evidence-based review". In: Byrne, J., Hummer, D. \& TAXman, F. S. The culture of prison violence. Boston, Pearson.

\& TaXman, Faye S. (2007), The culture of prison violence. Boston, Pearson.

CÁRDIA, Nancy. (s/d), "Raça, vitimização e direitos humanos". Núcleo de Estudos da Violência - USP. Disponível em <http:// www.nevusp.org/downloads/down065.pdfs.

Carvalho Filho, Luís Francisco. (2002), A prisão. São Paulo, Publifolha.

Chambliss, William J. (1967), "Types of deviance and the effectiveness of legal sanctions". Wisconsin Law Review, 703-719.

Chazkel, Amir. (2009), "Uma perigosíssima lição: a Casa de Detenção do Rio de Janeiro da Primeira República”. In: Maia, Clarisse Nunes, SÁ Neto, Flávio de, Costa, Marcos \& Bretas, Marcos Luiz (orgs.). História das prisóes no Brasil. Rio de Janeiro, Rocco, vol. 2.

Christie, Nils. (1986), “The ideal victim”. In: FATTAH, Ezzat. Crime policy to victim policy. Basingstoke, Macmillan.

. (1988), Los límites del dolor. México, Fondo de Cultura Económica.

CHubaty, Donna Elaine. (2001), Victimization, fear, and coping in prison. Dissertation-Abstracts-International:-Section-B:-The-Sciences-and-Engineering, vol. 62 (2-B). 
Clemmer, Donald. (1940), The prison community. Boston, Christopher Publishing. Coelho, Edmundo Campos. (2005), A oficina do diabo. Rio de Janeiro, Record.

Coelho, Harnoldo Colares et al. (2009), "Soroprevalência da infecção pelo vírus da hepatite B em uma prisão brasileira”. Revista Brasileira de Epidemiologia, 12 (2): 124-131.

CoHn, Ellen \& RotTon, James. (2003), "Even criminals take a holiday: instrumental and expressive crimes on major and minor holidays". Journal of Criminal Justice, 31: 351-360.

Coleman, James S. (1988), "Social capital in the creation of human capital". American Journal of Sociology, 94: 95-120.

Colorado, Fernando Díaz. (2006), "Una mirada desde las víctimas: el surgimiento de la victimología. Ensayo”. Umbral Científico, 9: 141-159.

Cooley, D. (1993), "Criminal victimization in male federal". Canadian Journal of Criminology, 35 (4): 479-495.

EdGAR, Kimmet. (2005), "Bullying, victimization and safer prisons". Probation Journal: The Journal of Community and Criminal Justice, 52 (4): 390-400.

, O’Donnell, Ian \& Martin, Carol. (2003), Prison violence: the dynamics of conflict, fear and power. Devon, William Publishing.

EliAs, Norbert. (1987), A sociedade de corte. Lisboa, Estampa.

GARLAND, D. (2001), The culture of control-crime and social order in contemporary society. Oxford, Oxford University Press.

Giddens, Anthony. (2003), The constitution of society. Cambridge, Polity Press.

HANNERZ, Ulf. (1980), Exploring the city: inquiries toward an urban anthropology. New York, Columbia University.

Hemmens, C. \& Marquart, J. W. (1999), “Straight time: Inmates' perceptions of violence and victimization in the prison environment". Journal of Offender Rehabilitation, 28 (3-4): 1-21.

Hope, Tim et al. (2001), “The phenomena of multiple victimization”. British Journal of Criminology, 41: 595-617.

IRELAND, Jane L. (2000), “'Bullying' among prisoners: a review of research”. $A g$ gression and Violent Behavior, 5 (2): 201-215.

. (2002), Bullying among prisoners: evidence, research and intervention strategies. East Sussex, Brunner-Routledge.

JefFerson, Tony. (2002), "Masculinities and crime”. In: Maguire, M., Morgan, Rod \& REINER, R. (eds.). The Oxford Handbook of Criminology. Oxford, Oxford University Press.

MARTElli, Celina Maria Turchi et al. (1990), "Soroprevalência e fatores de risco para a infecção pelo vírus da hepatite B pelos marcadores AgHBs e anti-HBs em prisioneiros e primodoadores de sangue". Revista de Saúde Pública, 24 (4): 270-276. 
Misse, Michel. (2011), “A categoria 'bandid' como identidade para o extermínio: algumas notas sobre sujeição criminal a partir do caso de Rio de Janeiro". In: Barreira, C., SÁ, L. \& AQUino, J. P. (orgs.). Violência e dilemas civilizatórios: as práticas de punição e exterminio. Campinas, Pontes.

MOUAT, Frederic John. (1891), "On prison ethics and prison labour". Journal of the Royal Statistical Society, 54 (2): 213-262.

Myers, David G. \& LAMMER, Helmut. (1976), "The group polarization phenomenon”. Psychological Bulletin, 83 (4): 602-627, jul.

NAGI, C., BROWNE, K. \& BLAKE, J. (2006), "A descriptive analysis of the nature and extent of bullying at a category C prison". British Journal of Forensic Practice, 8 (2): 4-9.

Nogueira, Péricles Alves \& AbrahĀo, Regina Maura Cabral de Melo. (2009), “A infecção tuberculosa e o tempo de prisão da população carcerária dos Distritos Policiais da zona oeste da cidade de São Paulo". Revista Brasileira de Epidemiologia, 12 (1): 30-38.

ONU. Subcomitê de Prevenção da Tortura e outros Tratamentos ou Penas Cruéis, Desumanos ou Degradantes. (2012), "Relatório sobre a visita ao Brasil do Subcomitê de Prevenção da Tortura e outros Tratamentos ou Penas Cruéis, Desumanos ou Degradantes". Disponível em <http://pfdc.pgr.mpf.gov.br/atuacao-e-conteudos-de-apoio/publicacoes/tortura/relatorio_visita_ao_Brasil_subcomite_prevencao_tortura_jun2012>.

PAes-Machado, Eduardo \& Albuquerque, Carlos Linhares. (2006), "The hazing of police recruits: initiation to organization and resistance to policing reform in Brazil”. In: DAuCÉ, Françoise \& SIECA-KozlowsKi, Elisabeth. Dedovshina in the post-soviet military: hazinz of Russian army conscripts in a comparative perspective. Stuttgart, Ibidem-Verlag, pp. 237-264.

\& Nascimento, Ana Márcia Duarte. (2011), “Bank employees don't go to Heaven: processes of victimization of bank employees for violent crimes". In: Hutcherson, Audrey N. (ed.). Psychology of victimization. New York, Nova Science Publishers, pp. 81-106.

\& Riccio-Oliveira, Maria Angélica. (2009), “O jogo de esconde-esconde: trabalho perigoso e ação social defensiva entre motoboys de Salvador”. Revista Brasileira de Ciências Sociais, 24 (70): 91-106, jun.

PAIXÃo, Antônio Luiz. (1987), Recuperar ou punir? Como o Estado trata o criminoso. São Paulo, Cortez.

Pérez, Deanna M., Gover, Angela R., Tennyson, Kristin M. \& SAntos, Saskia D. (2010), "Individual and institutional characteristics related to inmate victimization". International Journal of Offender Therapy and Comparative Criminology, 54 (3): 378-394. 
PORTO, Roberto. (2007), Crime organizado e sistema prisional. São Paulo, Atlas.

Ramalho, José Ricardo. (2002), O mundo do crime: a ordem pelo avesso. São Paulo, IBCCRIM.

SÁ, Alvino Augusto de. (1996), "Vitimização no sistema penitenciário". Revista do Conselho Nacional de Política Criminal e Penitenciária, 1 (8): 15-23.

SAlla, Fernando. (1999), As prisões em São Paulo: 1822-1940. São Paulo, Annablume/Fapesp.

SÁNCHEZ, Alexandra Roma et al. (2007), "A tuberculose nas prisóes do Rio de Janeiro, Brasil: uma urgência de saúde pública”. Cadernos de Saúde Pública, 23 (3): 545-552.

Sparks, Richard, Bottoms, Anthony E. \& Hay, Will. (1996), Prisons and the problems of order. Oxford, Clarendon Press.

Stowell, J. I. \& Byrne, J. M. (2007), "Does what happens in prison stay in prison?”. In: Byrne, J., Hummer, D. \& TAXMAN, F. S. The culture of prison violence. Boston, Pearson.

SYKES, Gresham M. (1958), The society of captives: a study of a maximum-security prison. Princeton, NJ, Princeton University Press.

Viggiani, N. (2007), "Unhealthy Prisons: exploring structural determinants of prison health". Sociology of Health \& Illness, 29 (1): 115-135.

WALKLATE, Sandra. (2003), Understanding criminology: current theoretical debates. Buckinghan, Philadelphia, Open University Press.

Ward, Tony. (2004), “State harms”. In: Hillyard, P., Pantazis, C., Tombs, S. \& GORDON, D. Beyond criminology: taking harm seriously. London, Pluto Press.

WolfF, Nancy et al. (2007), "Physical violence inside prison: rates of victimization". Criminal Justice and Behavior, 34 (5): 588-599.

\& SHI, Jing. (2011), "Patterns of victimization and feelings of safety inside prison: the experience of male and female inmates". Crime \& Delinquency, 57 (1): 29-55.

\& BACHMAN, Ronet. (2008), "Measuring victimization inside prisons". Journal of Interpersonal Violence, 23 (10): 1343-1362. 
Texto recebido em 3/8/2012 e aprovado em 24/1/2013.

Odilza Lines de Almeida é psicóloga, professora adjunta da Universidade Estadual do Sudoeste da Bahia (UESB) e servidora da Secretaria de Administração Penitenciária do Estado da Bahia. É mestre em psicologia e doutora em saúde coletiva (Universidade Federal da Bahia), com estágio doutoral em Salford (Reino Unido). E-mail: <odilzalines@uesb. edu.br>.

Eduardo Paes-Machado é professor associado do Departamento de Sociologia da Universidade Federal da Bahia e professor visitante da Michigan State University, com doutorado em ciências sociais (Universidade Estadual de Campinas, 1992), especialização e estágios de pós-doutorado em saúde do trabalhador na Universidade de Massachusetts (Estados Unidos) e criminologia nas Universidades de Toronto e York (Canadá) e Sheffield e Salford (Reino Unido).E-mail:<epaesm@gmail. com>.

\section{Resumo}

\section{Processos sociorganizacionais de vitimização prisional}

Este artigo analisa os padrões de vitimização de internos da maior unidade prisional da Bahia. Utiliza dados provenientes de um screening survey com 591 participantes, 107 entrevistas semiestruturadas e observação direta. Revela que mais da metade dos internos relatou ter sofrido algum tipo de vitimização material, física ou psicológica. Afirma que tais padrôes são influenciados pela violência da instituição, dos arranjos da cadeia e das quadrilhas prisionais. Também mostra a influência da disponibilidade de capitais econômico, cultural e social nos níveis de vulnerabilidade dos presos. Concluímos que o drama da vitimização dos internos é uma chave para compreender a dinâmica de um sistema prisional mais distópico do que podemos imaginar.

Palavras-chave: Prisão; Padrões de vitimização; Processos sociorganizacionais; Quadrilhas de internos; Vulnerabilidade.

\section{Abstract}

\section{Social processes of victimization in prisons}

This article analyzes patterns of victimization within the largest prison establishment in Bahia, using data from a screening survey with 591 participants, 107 semi-structured interviews and direct observation. The study reveals that more than half of the inmates had been victims of some sort of material, physical or psychological violence. The article finds that these patterns are structured by the violence of the institution, the prison arrangements and the prison gangs. It also shows the influence of economic, cultural and social capital on determining levels of vulnerability among prisoners. It concludes by affirming the importance of the State re-assuming its power to impose security, turning prisons less inhumane and reducing violence in penal institutions and society at large.

Keywords: Prison; Patterns of victimization; Socio-organizational processes; Prison gangs; Vulnerability. 